\title{
TINJAUAN SOSIOLOGI HUKUM TERHADAP CORPORATE SOCIAL RESPONBILITY (CSR) SEBAGAI ETIKA BISNIS DAN ETIKA SOSIAL
}

\author{
Putu Edgar Tanaya \\ Fakultas Hukum \\ Universitas Udayana \\ E-mail: edgartanaya43@gmail.com
}

\begin{abstract}
ABSTRAK
Perseroan merupakan badan hukum layaknya manusia yang mempunyai organ serta saling mempengaruhi dan dipengaruhi pihak lain. Suatu perseroan tidak hanya memperhatikan kepentingan para pemegang saham (shareholder), namun juga harus memperhatikan kepentingan pihak - pihak yang terafiliasi dengan aktivitas perusahaan seperti karyawan, masyarakat, termasuk juga lingkungan sekitar tempat perseroan melakukan usahanya (stakeholder). Melalui pelaksanaan corporate social responsibility (CSR), perseroan bertanggung jawab memperhatikan kepentingan para stakeholdernya sehingga antara kegiatan mencari keuntungan (profit oriented) dan kegiatan sosial dapat berjalan secara seimbang. Pelaksanaan CSR tentunya akan memberikan keuntungan baik materil maupun imateril kepada stakeholder, namun pelaksanaan CSR juga memberikan keuntungan untuk perseroan. Melalui pelaksanaan CSR, kegiatan bisnis perseroan akan dapat berjalan secara berkelanjutan (sustainable) karena mendapat dukungan dari dari para stakeholder. Berdasarkan hal tersebut CSR menjadi etika bisnis dan etika sosial perseroan dalam menjalankan usahanya.
\end{abstract}

\section{Kata Kunci: Tanggung Jawab Sosial Perusahaan, Etika Bisnis, Etika Sosial}

\section{ABSTRACT}

Legal entities such as human beings have organs and affect each other and influenced others. The company is not only responsible for the shareholders, but also to be responsible for the interest of stakeholders. Throught the implementation of corporate social responsibility will create a balance between profit and social activities. The implementation of corporate social responsibility would provide profit and/or benefit to the stakeholder, but the implementation of corporate social responsibility will also provide profit and/or benefit to company. The company's business activities will be run in a sustainable manner, due to the support of stakeholders. so, corporate social responsibility is a business ethics and social ethics of the company in running its business.

\section{Key words: Corporate Social Responsibility, Business Ethics, Social ethics}

\section{Pendahuluan}

Perkembangan dunia usaha di Indonesia telah memasuki era globalisasi, sehingga dunia usaha dituntut untuk berkembang semakin pesat. Kondisi yang demikian ini mengakibatkan munculnya perseroan (Pasal 1 butir (1) Undang-Undang No.40 tahun 2007 ) yang melakukan usaha diberbagai bidang. Berbicara mengenai perseroan, maka tidak dapat dilepaskan dengan tujuan dari 
perseroan itu sendiri. Perseroan berdiri tidak mungkin tanpa suatu tujuan tertentu, perseroan yang dilatarbelakangi oleh adanya kebutuhan masyarakat tersebut, tumbuh dan berkembang dengan tujuan utama yaitu keuntungan (profit oriented)

Seiring dengan tujuan utama dari perseroan, perkembangan dunia usaha dewasa ini tidak dapat dipisahkan dengan lingkungan eksternalnya. Lingkungan eksternal yang dimaksud adalah selain mengejar keuntungan suatu perseroan juga harus memperhatikan masyarakat dan lingkungan sekitarnya, agar semua aktifitas dapat berjalan dengan seimbang.

Kenyataan tidak sejalan dengan pengharapan, perseroan masih menunjukan sikap "acuh tak acuh" terhadap peranan masyarakat dalam suatu perseroan, dengan alasan dadil bahwa perusahaan hanya mencari keuntungan dan atau laba (Azheri, 2008). Menyikapi kondisi tersebut, dalam dunia usaha muncul berbagai diskursus yang berkaitan dengan pengelolaan dunia usaha itu sendiri, terutama berkaitan dengan tanggung jawab yang harus diemban oleh suatu perusahaan. Salah satu yang muncul adalah terminologi tanggung jawab sosial perusahaan yang dalam bahasa inggris disebut sebagai Corporate Social Responsibility (selanjutnya disingkat CSR).

CSR telah menjadi sebuah isu global, namun belum ada satu defenisi tunggal dari CSR yang diterima secara global. Secara etimologis CSR dapat diartikan sebagai tanggung jawab sosial perusahaan atau korporasi. CSR kini jadi frasa yang semakin populer dan marak diterapkan perusahaan di berbagai belahan dunia.

Di Indonesia, konsep CSR semakin menguat terutama setelah dinyatakan dengan tegas dalam Undang-Undang No 40 Tahun 2007 Tentang Perseroan Terbatas (selanjutnya disingkat UUPT), Dalam UUPT Pasal 1 angka 3, dinyatakan: "Tanggung Jawab Sosial dan Lingkungan adalah komitmen Perseroan untuk berperan serta dalam pembangunan ekonomi berkelanjutan guna meningkatkan kualitas kehidupan dan lingkungan yang bermanfaat, baik bagi Perseroan sendiri, komunitas setempat, maupun masyarakat pada umumnya". Kemudian Pasal 74 ayat (1), menyatakan: "Perseroan yang menjalankan kegiatan usahanya di bidang dan/atau berkaitan dengan sumber daya alam wajib melaksanakan Tanggung Jawab Sosial dan Lingkungan". Lahirnya kedua undang - undang tersebut "memaksa" perseroan untuk melaksanakan CSR dengan disertai sanksi jika tidak melaksanakannya.

Perumusan CSR ke dalam peraturan perundang - undangan tersebut sebagai akibat banyaknya perseroan yang hanya melakukan kegiatan operasionalnya namun kurang memberikan perhatian terhadap kepentingan sosial. padahal antara perusahaan, masyarakat, dan lingkungan merupakan satu kesatuan yang tidak dapat dipisahkan sehingga diantara ketiganya saling mempengaruhi dan dipengaruhi.

Berdasarkan latar belakang diatas menjadi menarik bagi penulis untuk mengkaji dari pandangan sosiologi hukum mengenai tanggung jawab sosial dan lingkungan (CSR) sebagai etika bisnis dan etika sosial 


\section{Perspektif CSR Sebagai Etika Bisnis dan Etika Sosial dari Pandangan Sosiologi Hukum}

Manusia adalah pendukung hak dan kewajiban. Lazimnya dalam hukum dan pergaulan hukum dikenal dengan istilah subyek hukum. Tetapi manusia bukanlah satu-satunya subyek hukum, karena masih ada subyek hukum lainnya yaitu segala sesuatu yang menurut hukum mempunyai hak dan kewajiban, termasuk apa yang dinamakan badan hokum (Ali, 2011).

Menurut kenyataan yuridis, badan hukum adalah wujud riil, sama riilnya dengan manusia dan lain-lain perikatan (verbintenis) (Ali, 2011,). Badan hukum dari awal lahirnya sampai pertanyaan mengenai eksistensi badan hukum banyak menimbulkan perdebatan (debatable). Secara fiksi badan hukum diperlakukan seperti manusia, sehingga seharusnya (ideal) suatu badan hukum juga berperilaku seperti manusia.

Manusia dalam kenyataannya sebagai mahluk sosial, banyak aspek eksternal diluar diri manusia yang perlu diperhatikan demi terciptanya kehidupan yang harmonis, nyaman, dan seterusnya. Sama halnya dengan badan hukum, dalam kenyataan yuridis badan hukum pun beriteraksi dengan aspek-aspek eksternal dari badan hukum tersebut. Badan hukum perlu melakukan hubungan hukum berlandaskan kepercayaan, sehingga hubungan-hubungan hukum tersebut dapat terealisasikan dengan baik dengan badan hukum atau subyek hukum yang lain.

Manusia dalam kehidupan bisnis merupakan pelaku dalam aktifitas-aktifitas bisnis, selain manusia badan hukum juga merupakan pelaku bisnis yang menjalankan aktifitas-aktifitas bisnis. Begitu juga kaidah bisnis tersebut ada kaedah-kaedah hukum yang mengatur. Dapat dikatakan kaedahkaedah hukum tersebut sebagai petunjuk oleh pelaku-pelaku bisnis tersebut untuk bertindak dalam menjalankan bisnis.

Bisnis tidak serta merta / tidak begitu saja dapat diartikan segala tindakan-tindakan / usaha-usaha / kerjasama - kerjasama dalam memperoleh keuntungan (profit oriented). Telah terjadi perubahan paradigm (Kuhn, 1970) dimana kegiatan badan hukum dalam melaksanakan aktifitas-aktifitas bisnis untuk kepentingan mendapatkan profit atau memberikan deviden kepada pemegang saham (shareholder) akan tetapi telah bergeser dari awalnya hanya memperhatikan kepentingan shareholder saja tapi perhatian juga tertuju kepada stakeholder.

Pendekatan stakeholder ini sebenarnya sudah diterapkan oleh masyarakat tradisional, misalnya masyarakat adat Bali. Di Bali dikenal istilah tri hita karana yang menekankan keseimbangan hubungan antara tuhan (parhyangan), sesama manusia (pawongan), dan lingkungan (palemahan). Keseimbangan akan tercipta jika ketiga hal tersebut dapat berjalan beriringan satu sama lain. Masuknya pengaruh - pengaruh ekonomi yang menekankan pada pendekatan shareholder (efisiensi) merubah paradigma masyarakat dalam menjalankan bisnis. Namun dengan munculnya pendekatan stakeholder dewasa ini, membuktikan bahwa kembali terjadi perubahan paradigma masyarakat bahwa dalam 
menjalankan kegiatan bisnis. Perusahaan yang menjalankan kegiatan bisnis harus menyeimbangkan antara pendekatan ekonomi (profit oriented) dan budaya sosial (tanggung jawab sosial) sehingga segala sesuatu berjalan secara berkelanjutan.

\section{Pendekatan}

stakeholder

digunakan khususnya sebagai etika bisnis yang mengintegrasikan kepentingan bisnis disatu pihak dan tuntutan etika dipihak lain (Keraf, 2012). Dasar pemikiran dari pendekatan stakeholder bahwa semua pihak yang punya kepentingan dalam suatu kegiatan bisnis terlibat di dalamnya karena ingin memperoleh keuntungan, maka hak dan kepentingan mereka harus diperhatikan dan dijamin. Pada akhirnya dengan pendekatan stakeholder bermuara pada prinsip tidak merugikan hak dan kepentingan para pihak berkepentingan mana pun dalam suatu kegiatan bisnis.

Kultur

perusahaan

berparadigma dan memfokuskan perhatian kepada stakeholder tidak hanya mendapatkan nilai tambah pada profit saja, akan tetapi bisa memperoleh kemanfaatan lebih (benefit) demi kelangsungan usahanya. Sebuah perusahaan/badan hukum yang berparadigma stakeholder tidak hanya menempatkan esensinya hanya pada entitas bisnis semata tetapi merupakan juga bagi entitas-entitas yang lain.

Badan Hukum dalam menjalankan usahanya tidak luput dari dampak yang diakibatkan olehnya, sehingga kenyataan yuridis yang menyebabkan dia ada sepatutnya pula dilihat dari perspetif kenyataan sosial dimana ia berada, sehingga perihal keberadaannya tersebut harus diimbangi juga dengan tanggung jawab terhadap lingkungan sosial dia berada.

Konsep tersebut populer disebut dengan corporate social responsibility (CSR). Dalam pelaksanaan CSR ini sebenarnya ada hubungan timbal balik yakni saling membutuhkan dan saling mempengaruhi antara perseroan dengan stakeholder, di satu sisi stakeholder tentunya merasakan manfaat peningkatan kualitas hidup dari pelaksanaan CSR tersebut dan disisi lain perseroan juga merasakan manfaat dari pelaksanaan CSR tersebut yakni kelancaran kegiatan usaha yang dilakukan oleh perseroan tanpa hambatan dari faktor eksternal dan mendapat keuntungan sosial berupa kepercayaan (trust) dari stakeholder. Disini terlihat pelaksanaan CSR tidak hanya memberikan manfaat hanya untuk perusahaan dan shareholder saja tetapi juga memberikan manfaat juga untuk stakeholder (greatest happiness of the greatest number).

Masyarakat merupakan salah satu stakeholder yang juga memberikan andil dalam kelancaran aktifitas suatu badan hukum / perusahaan, Masyarakat yang berada di sekitar perusahaan adalah salah satu pemangku kepentingan utama dari sistem perusahaan. Ini tidak terlepas dari hakekat bahwa masyarakat memberikan dukungan akan keberlangsungan operasinal perusahaan. Sebagai pihak yang memangku kepentingan (stakeholders) utama, maka masyarakat setempat harus dianggap sebagai bagian dari perusahaan.

Perhatian terhadap masyarakat dapat dilakukan dengan cara 
melakukan aktivitas-aktivitas serta pembuatan kebijakan-kebijakan yang dapat meningkatkan kompetensi yang dimiliki di berbagai bidang. Kompetensi yang meningkat ini pada gilirannya diharapkan akan mampu dimanfaatkan bagi peningktan kualitas hidup masyarakat. Dengan menjalankan CSR, perusahaan diharapkan tidak hanya mengejar keuntungan jangka pendek, namun juga turut berkontribusi bagi peningkatan kesejahteraan dan kualitas hidup masyarakat dan lingkungan sekitar dalam jangka panjang.

Elkington (2010) menjelaskan bahwa ketiga unsur yakni profit, people, dan planet senantiasa berada dalam kondisi kait-mengkait. Keuntungan memang merupakan bagian yang terpenting dan juga sebagai tujuan utama dari setiap aktivitas ekonomi perusahaan. Dengan diperolehnya keuntungan, perusahaan dapat memberikan deviden bagi pemegang saham, mengalokasikan sebagian keuntungan yang diperoleh guna membiayai pertumbuhan dan pengembangan usaha di masa depan, serta membayar pajak. Alokasi dana yang tercantum di dalam laporan tahunan yang diperoleh guna membiayai pembangunan usaha di masa depan merupakan bentuk tanggung jawab perusahaan dalam menjalankan bisnisnya terhadap sosial dan lingkungan sekitar.

CSR dalam pelaksanaannya tentu memerlukan perangkatperangkat kaedah hukum yang baik untuk menjamin bahwa CSR ini pelaksanaannya dapat berjalan secara berkelanjutan, maka dalam pembuatan suatu kaedah hukum tentang CSR tidak hanya memperhatikan sisi yuridisnya saja karena hukum itu sendiri tidak bebas nilai (interdisipliner) yakni hukum mempengaruhi dan dipengaruhi oleh sub-sub sistem lain seperti Budaya Sosial, Sosial, Politik, Ekonomi (Rahardjo, 1991). Sehingga banyak hal yang harus dijadikan pertimbangan dalam pembentukan suatu peraturan perundangundangan agar hukum tersebut dapat diterima oleh masyarakat (mempunyai keberlakuan sosiologis). Kembali lagi suatu hukum diciptakan untuk manusia bukan untuk hukum itu sendiri, jadi dalam pembuatan peraturan tentang CSR itu sendiri harus sesuai dengan jiwa masyarakat sehingga peraturan tersebut dapat dilaksanakan dengan penuh kesadaran karena dirumuskan sesuai dengan nilai-nilai yang hidup di dalam masyarakat.

Badan hukum yang beretika dalam berbisnis tentunya baik ada ataupun tidak suatu aturan yang mengatur sudah selayaknya mempunyai andil dalam pembangunan nasional dengan melaksanakan tanggung jawab sosial dan lingkungan secara berkelanjutan. Dengan memulai mengkomunikasikan kegiatan CSR mereka melalui penyelarasan kebijakan, penyusunan perencanaan strategis, pelaksanaan mekanisme kerja hingga pada monitoring, evaluasi dan pendokumentasian pelaksanaan kegiatan. Dengan demikian, perusahaan dapat mengindentifikasi beberapa langkah prioritas sekaligus menunjukkan bagaimana rangkaian kegiatan CSR ini secara significant dapat membawa perbaikan dalam peningkatan kualitas hidup masyarakat dan juga pelestarian fungsi lingkungan, 
dimana pada akhirnya akan menjaga keberlanjutan pembangunan secara menyeluruh.

Kenyataan yuridis dan sosial inilah, menempatkan para pemikirpemikir layaknya manusia dalam lingkungan sosial diikat oleh etikaetika, kaidah-kaidah baik etika bisnis maupun etika sosial.

\section{Kesimpulan}

Dari pandangan sosiologi hukum pelaksanaan CSR sebagai etika bisnis dan etika sosial merupakan suatu tanggung jawab badan hukum mengingat badan hukum merupakan subyek hukum yang dalam kenyataan yuridis disejajarkan seperti manusia sebagai subyek hukum yang utama. sehingga konsekunsinya ketika manusia sebagai mahluk sosial memiliki banyak aspek eksternal yang harus diperhatikan yang dalam hal ini memperhatikan stakeholder termasuk lingkungan hidup melalui pelaksanaan CSR.

Setiap perlakukan yang dilakukan perusahaan terhadap aspek-aspek eksternal tersebut pada akhirnya akan mempengaruhi keberlanjutan dan perkembangan badan hukum tersebut.

\section{Daftar Pustaka}

Ali, Chidir, 2011, Badan Hukum, cetakan keempat, PT. Alumni, Bandung

Huijbers, Theo, 1995, Filsafat Hukum, Kanisus, Yogyakarta.

Keraf, A. Sonny, 2012, Etika Bisnis: Tuntutan dan Relevansiny, cetakan ke-16, Kanisus, Yogyakarta

Kuhn, Thomas Samuel, 1970, The Sturcture of Scientific Revolution, The University of Chicago Press,
Chicago, diterjemahkan Tjun Surjaman, 2012, Peran Paradigma dalam Revolusi Sains, Cetakan ke-7, Pt. Remaja Rosdokarya, Bandung.

Rahardjo, Satjipto, 1991, Ilmu Hukum, PT Citra Aditya Bakti, Bandung

Siagian, Matias dan Agus Suriadi, 2010, CSR Perspektif Pekerjaan Sosial, FISIP USUPress, Medan.

Wahyudi, Isa dan Busyra Azheri, 2008, corporate social responsibility: Prinsip, Pengaturan dan Implementasi, In-Trans Publishing, Malang.

\section{Undang-Undang}

Undang-Undang Nomor 25 Tahun 2007 tentang Penanaman Modal (Lembaran Negara Republik Indonesia Tahun 2007 Nomor 67, Tambahan Lembar Negara Republik Indonesia Nomor 4724).

Undang-Undang Nomor 40 Tahun 2007 tentang Perseroan Terbatas (Lembaran Negara Republik Indonesia Tahun 2007 Nomor 106, Tambahan Lembar Negara Republik Indonesia Nomor 4756). 